\title{
Infection by Parvicapsula sp. (Myxozoa) is associated with mortality in sea-caged Atlantic salmon Salmo salar in northern Norway
}

\author{
Erik Sterud*, Pernilla Simolin, Agnar Kvellestad
}

National Veterinary Institute, PO Box 8156 Dep., 0033 Oslo, Norway

\begin{abstract}
In March 2002, 3 seawater farms in northern Norway experienced high mortality among Atlantic salmon postsmolts. A myxosporean parasite assigned to the genus Parvicapsula was detected in the pseudobranchs of diseased fish, and extensive destruction of this organ was observed. The parasite was also found in the gills, liver and kidney of some fish. Based on host species, spore morphology, and the unusual site preference of the parasite, it is likely that it represents a hitherto undescribed species. The diseased fish had been transferred to seawater in September 2001, and it is believed that the infection took place shortly after exposure to seawater. The source of infection is unknown.
\end{abstract}

KEY WORDS: Atlantic salmon - Aquaculture - Myxosporea · Norway $\cdot$ Parvicapsulosis $\cdot$ Pseudobranch

Resale or republication not permitted without written consent of the publisher

Myxosporeans in the genus Parvicapsula are potential pathogens of both wild and farmed fish. Parvicapsula minibicornis Kent, Whitaker \& Dawe, 1997 has caused high mortality in pre-spawning sockeye salmon Oncorhynchus nerka in the Fraser River watershed in British Columbia, Canada (Raverty et al. 2000, StHilaire et al. 2002). Parasite-induced destruction of renal glomeruli and tubules was reported as the cause of death (Raverty et al. 2000). An unidentified Parvicapsula species was reported to have caused significant mortality in sea-farmed coho salmon Oncorhynchus kisutch in Washington and Oregon, USA (Hoffman 1984, Johnstone 1984). Seven other species of Parvicapsula have been described from the urinary system of a number of marine fish (Shulman 1953, Kabata 1962, Evdokimova 1977, Kovaljeva \& Gaevskaya 1981, Dorothy \& Kalavata 1993, Landsberg 1993, Zhao et al. 2000).

In March 2002, severe mortality was recorded in a fish farm (A) in northern Norway. By the end of April 2002, $35 \%$ of 200000 Atlantic salmon Salmo salar transferred to seawater in September 2001 were lost. Myxosporeans, subsequently assigned to the genus Parvicapsula, were found in the pseudobranchs of diseased fish submitted to the National Veterinary Institute. A few weeks later, similar parasites were found in fish from 2 other fish farms (B and C), where mortality was modest (2 to $3 \%$ ). Myxosporeans in the genus Parvicapsula have not previously been reported as pathogenic parasites in farmed Atlantic salmon, and the apparent preference for the pseudobranches represents a new feature for these parasites. Observations made on parasites and fish in these cases are presented here.

Materials and methods. The affected fish farms are located in the Alta Fjord, $70^{\circ} 15^{\prime} \mathrm{N}, 23^{\circ} 30^{\prime} \mathrm{E}(\mathrm{A})$, Tana Fjord $70^{\circ} 15^{\prime} \mathrm{N}, 28^{\circ} 0^{\prime} \mathrm{E}(\mathrm{B})$ and Lyngen Fjord $69^{\circ} 45^{\prime} \mathrm{N}$, $20^{\circ} 30^{\prime} \mathrm{E}$ (C). Farms A and B had received smolts of the same stock and from the same hatchery, while the fish in Farm $\mathrm{C}$ were of a different origin. All diseased fish had been transferred to seawater in September 2001, as $0+$ smolts. The water temperature was approximately $3^{\circ} \mathrm{C}$ and salinity was approximately $33 \%$ in May 2002, when fish with clinical signs of disease were sampled for examination. Fish (20, 10 and 10; 200 to $300 \mathrm{~g}$ ), from Farms A, B and C, respectively, were submitted on ice for autopsy. Formalin-fixed organs and fresh blood samples from an additional 10 fish were sent from Farm B. Fish from Farms A, B and C $(14,17$ and $9 ; 40$ in total) were autopsied, while haematocrit values were recorded in all 40 fish sent from Farms A and B.

Wet-mount squeeze preparations of several organs were examined under a phase contrast light microscope. Tissue samples were fixed in formalin and embedded in paraffin for histological examination. Sections were stained with haematoxylin and eosin (H\&E) and selected serial sections were stained according to Perls' Prussian blue method for the detec- 
tion of ferric iron. Additional tissue samples, cut in small pieces, were fixed in $3 \%$ cacodylate buffered glutaraldehyde while shaken, to release spores for scanning electron microscopy (SEM). Fixed spores were post-fixed in $1 \%$ osmium tetroxide, dispersed on a nucleopore filter, gold-sputtered and viewed in a JEOL JSM 6400 scanning microscope.

All fish from Farm A were examined for bacterial and viral infections. Kidney samples for bacteriology were streaked onto blood agar plates with and without additional supplementation of $2 \% \mathrm{NaCl}$, and incubated at 15 and $22^{\circ} \mathrm{C}$, respectively, for $6 \mathrm{~d}$. Kidney samples for virology were inoculated into cultures of BF-2, EPC and CHSE-214 cells (Dannevig et al. 2001).

Results. Macroscopic observations: Clinical signs of disease included sluggish swimming and exophthalmia. The diseased fish were in normal to poor condition. Little or no feed was observed in the gastrointestinal tract. Crescent-shaped haemorrhages were seen in the eyes of many fish $(n>20)$. Petecchial haemorrhages were seen on the inside of the operculae and in the skin on the anterior abdomen of a few fish $(n<10)$. The pseudobranchs were covered with a white matter, and the filaments of gill arches in immediate vicinity of affected pseudobranchs were whitish in a few fish $(n<$ 10). The livers of several fish were pale or curry-yellow $(n>20)$. Haemorrhages in liver and/or in the peritoneal cavity were seen in a few fish $(\mathrm{n}<10)$. Vaccineinduced fibrous peritonitis was observed in all fish. Mean haematocrit values of 26 and $22 \%$ in Farms A and $\mathrm{B}$, respectively, indicated anaemia.

Microscopic observations and histopathology: $\mathrm{Nu}-$ merous structures identified as spores and disporic pseudoplasmodia of a myxosporean parasite were present in wet mount preparations of pseudobranch, gill and liver tissue (Figs. $1 \& 2$ ). The spores were asymmetrical, slightly curved, and with 1 of the 2 unequal spore valves ending in a caudal projection (Figs. 1 to 5). Fresh spores measured with an ocular micrometer had a mean length of $14.4 \mu \mathrm{m}$ (13.8 to $15.1 \mu \mathrm{m})(\mathrm{n}=15)$, and mean width was $7.2 \mu \mathrm{m}(6.3$ to $7.8 \mu \mathrm{m})$. Two subspherical polar capsules were located in the anterior end of the spores, 1 posterior to the other (Figs. 1 \& 2). The mean diameter of the polar capsules was $3.0 \mu \mathrm{m}$ (2.5 to $3.2 \mu \mathrm{m})$.

The parasites were present in wet mount preparations and/or histological sections of pseudobranchs from all fish $(\mathrm{n}=40)$. In the most severely affected pseudobranchs there were high numbers of spores and pseudoplasmodia in the capillaries, epithelium and connective tissue, with only small areas of apparently normal tissue remaining (Figs. 7 to 9). A moderate number of predominantly mononuclear inflammatory cells were seen in the lamellae and in the surrounding connective tissue. Spores and pseudoplasmodia, similar to those found in the pseudobranchs, were also found in gills, liver and kidney of 7, 6 and 1 fish, respectively (Figs. 10 \& 11). Few to high numbers of inflammatory cells were seen in the gill filamental epithelium and central venous sinus. The number of leucocytes in circulating blood was elevated. Moderate to extensive amounts of ferric iron were stored in many macrophage-like cells in the spleen (Fig. 12). There was a moderate hyperplasia of melanomacrophages in the kidney. A low number of inflammatory cells were seen in the endocardium of most fish.
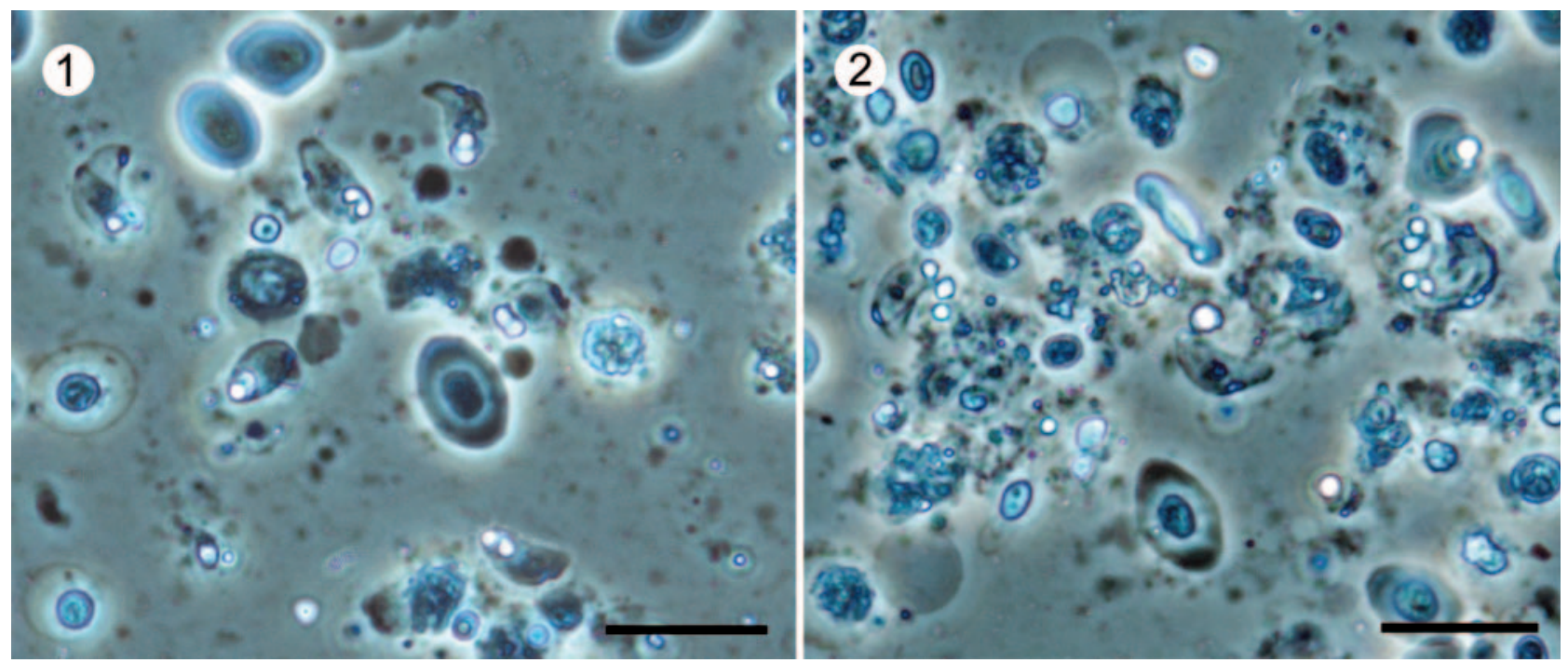

Figs. 1 \& 2. Salmo salar. Fresh scrapings of pseudobranchs from Atlantic salmon infected with Parvicapsula sp. Scale bars $=20$ um. Fig. 1. Spores of Parvicapsula sp. Fig. 2. Disporic pseudoplasmodia of Parvicapsula sp. 

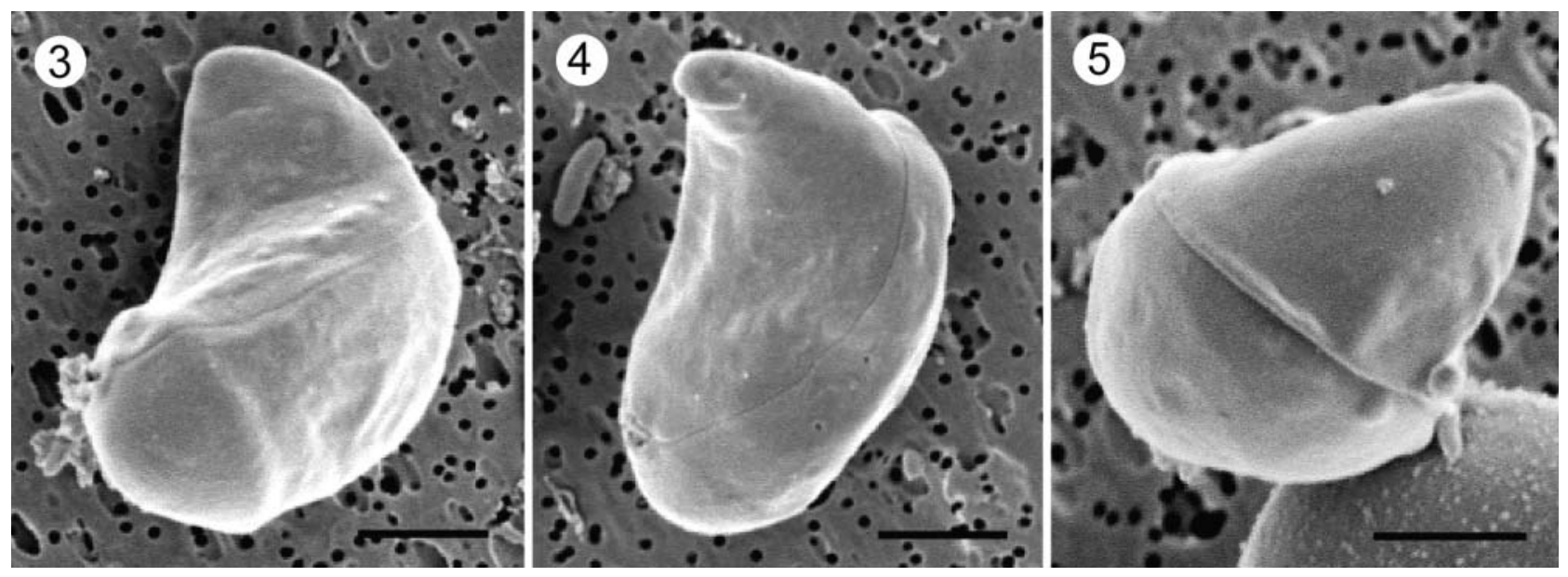

Figs. 3 to 5. Salmo salar. Parvicapsula sp. spores from Atlantic salmon liver. Scale bars $=3 \mu \mathrm{m}$

Microbiology: Moritella viscosa grew abundantly in pure culture from the kidney of 1 fish, which, however, did not display septicaemic changes. No other bacteria were cultured and no viruses were detected.

Discussion. The myxosporean parasites found in the pseudobranchs of farmed Atlantic salmon are assigned to the genus Parvicapsula. This is based on the following morphological characteristics: disporic pseudoplasmodia, and asymmetrical spores with a caudal projection on 1 of the 2 unequal spore valves (see Shulman 1966, Lom \& Dykova 1992). Compared to other Parvicapsula species isolated from salmonids, the spores most closely resemble those of a Parvicapsula sp., reported to cause high mortality in farmed coho salmon from Washington, USA (Hoffmann 1984, Johnstone 1984). The spores of $P$. minibicornis, which causes disease in wild sockeye salmon in the Fraser River, Canada, are clearly different, being symmetrical, with pyriform polar capsules, and 2 caudal projections (Kent et al. 1997). The present species best fits the description of $P$. unicornis Kabata, 1962, described from the urinary bladder of Limanda limanda, Callionymus lyra and Lepidorhombus whiffiagonis from the North Sea. However, the smaller spores of this species, 7 to $8 \mu \mathrm{m}$ according to Kent et al. (1997) and $12 \mu \mathrm{m}$ according to Lom \& Dykova (1992), together with the differences in organ and host preference, indicate that the present species from farmed salmon is a different and thus undescribed species. Until a closer description is made, the present myxosporean is tentatively designated as a Parvicapsula sp.

Based on macroscopic, histopathological and haematological findings we believe that the observed mortality in farmed Atlantic salmon can be attributed to the isolated Parvicapsula sp. The extensive destruction of the pseudobranchs indicates loss of function. Al- though its function is not fully understood, the pseudobranch is most probably responsible for the supply of oxygen to the retina of the fish eye (Wittenberg \& Wittenberg 1962, Fairbanks et al. 1969, Bridges et al. 1998). Additional sensory roles linked to blood parameters such as $\mathrm{Na}^{+}$concentration, osmotic pressure, $\mathrm{pH}$ and $\mathrm{O}_{2} / \mathrm{CO}_{2}$ concentration have also been suggested (see Bridges et al. 1998).

The occurrence of parasites in extra-pseudobranchial locations was probably underestimated, as the organisms were difficult to recognize in sections. Nevertheless, the demonstration of parasites in different organs combined with haemorrhages within the eye, leucocytosis, branchitis and endocarditis clearly indicate a systemic infection. The anemia and extensive iron storage in the spleen indicate that the infection results in increased destruction and/or reduced production of red blood cells.

The source of infection in the present cases of parvicapsulosis is unknown. The genus Parvicapsula is considered a marine genus (Kent et al. 2001), which indicates infection following seawater transfer. Based on the existing knowledge of myxosporeans, it is assumed that the fish have been infected by spores within, or released from, an intermediate host. The high parasite prevalence and death of many fish at the same time indicate a massive infection within a relatively short period of time. No disease was observed among fish transferred to sea as yearlings during spring 2001 from Farm A, or in October 2001 from Farm B. These fish were not examined for parasites, but this observation suggests that infection was restricted to a short period of time after sea transfer in September 2001. It is likely that infection with the present Parvicapsula sp. is restricted to the autumn. Seasonal dependence of development has been seen in other myxosporeans 


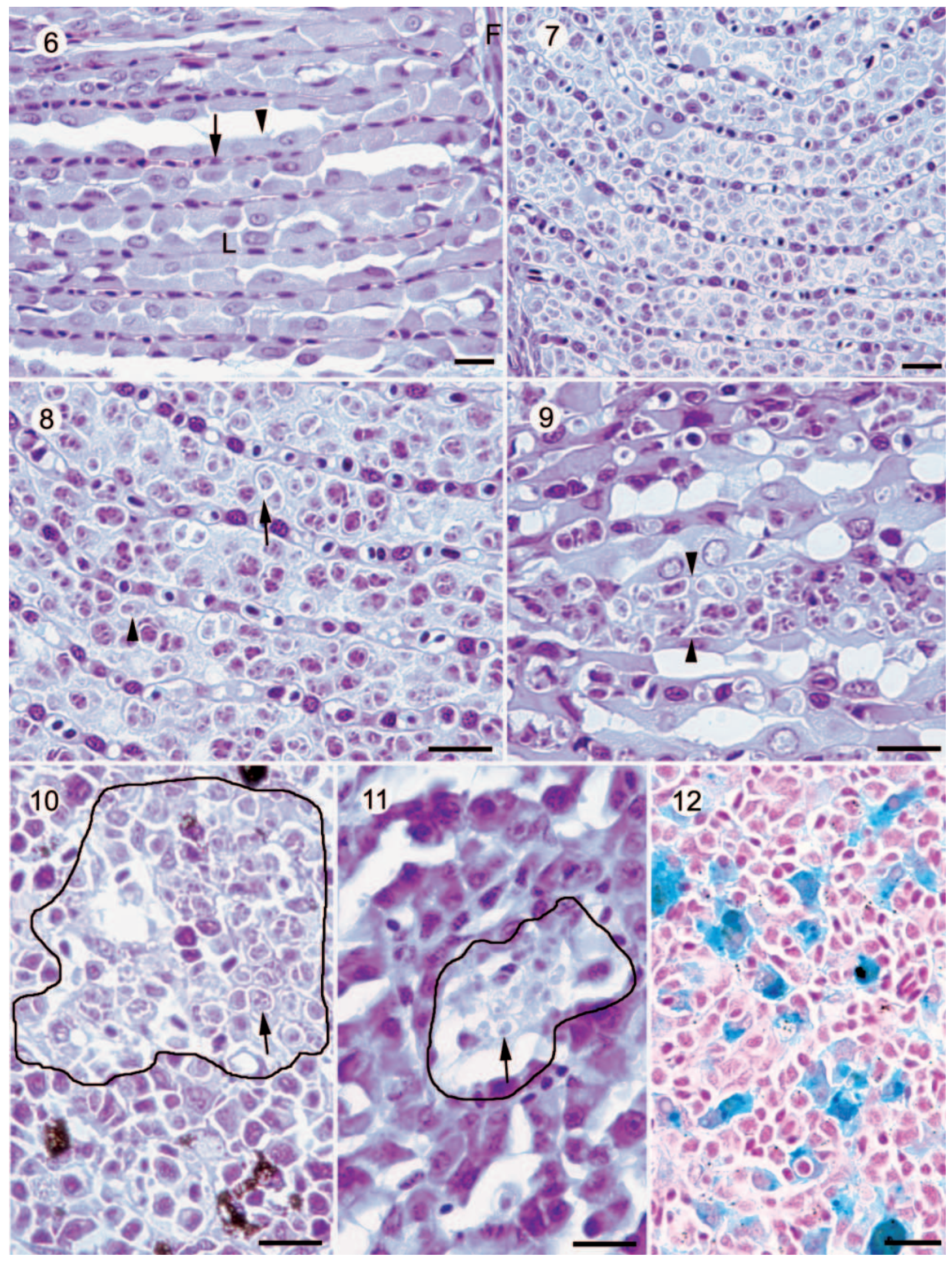


Figs. 6 to 12. Salmo salar. Histological sections from Atlantic salmon stained with haematoxylin and eosin (H\&E) or Perl's Prussian blue method. Scale bars $=20 \mu \mathrm{m}$. Fig. 6. Normal pseudobranch with part of filament (F) and lamellae (L) with epithelial cells (arrowhead) and pillar cells of the vascular system (arrow). H\&E. Fig. 7. Pseudobranch from fish infected with Parvicapsula sp. Large numbers of parasite spores and pseudplasmodia between lamellae are visible. H\&E. Fig. 8. Spores (arrowhead) and pseudoplasmodia (arrow) of Parvicapsula sp. between pseudobranch lamellae. Loss of epithelial cells is visible. Fig. 9. Spores and pseudoplasmodia of Parvicapsula sp. within a pseudobranch lamellar capillary (between arrowheads). H\&E. Fig. 10. Parvicapsula sp. in kidney interstitium. Affected area encircled. Arrow marks 1 of several parasitic spores. H\&E. Fig. 11. Parvicapsula sp. in liver. Affected area encircled. Arrow marks 1 of several parasitic spores. H\&E. Fig. 12. Extensive amounts of ferric iron (blue) in many macrophage-like cells in the spleen from fish infected with Parvicapsula sp. (Prussian blue)

such as Henneguya psorospermica, which produces mature plasmodia in the gills of perch Perca fluviatiliis only in late winter/early spring (Lom \& Dykova 1992).

Parvicapsula sp. infections in Atlantic salmon may have been allowed to go undetected for a longer period, as examinations of diseased fish from Norwegian farms have not routinely included the pseudobranch, and as the parasites are difficult to see in sections of other organs. A re-examination of cases of high mortality and gill inflammation of unknown cause may therefore be appropriate. The severity of the disease caused by Parvicapsula sp. in the present cases also calls for an exact identification of the parasite and elucidation of its life cycle.

Addendum. In July 2002, Parvicapsula sp. was detected in a fourth farm in which smolt from several hatcheries had been transferred to sea as 1+ smolts in May 2001. Thirty fish were examined, and all had severely damaged or missing pseudobranchs. However, Parvicapsula spores were only found in 4 fish. The apparent reason for this is that the spore excretion period was near its end. This finding shows that infection is not restricted to fish transferred to sea in the autumn. We believe that even the spring smolt became infected in September 2001 since this fish did not develop parvicapsulosis earlier than fish from Farms A, $\mathrm{B}$ and $\mathrm{C}$.

Acknowledgements. Special thanks are given to Lena Iversen, Elisabeth Myklebust, Herdis Gaup Aamot and Solfrid Åmdal for field work, and Kari Norheim for initial diagnostic work. We also thank Dr. Duncan Colquhoun and Dr. Birgit H. Dannevig for bacteriological and virological examinations, respectively. Finally, we thank Dr. Trygve T. Poppe for editorial comments.

\section{LITERATURE CITED}

Bridges CR, Berenbrink M, Muller R, Waser W (1998) Physiology and biochemistry of the pseudobranch: an unanswered question? Comp Biochem Physiol 119A:67-77

Dannevig BH, Olesen NJ, Jentoft S, Kvellestad A, Taksdal T, Håstein T (2001) The first isolation of a rhabdovirus from perch (Perca fluviatilis) in Norway. Bull Eur Assoc Fish Pathol 21:186-194

Dorothy KP, Kalavata C (1993) Parvicapsula hoffmani sp. n.
(Myxozoa: Parvicapsulidae) from the mullet, Liza macrolepis (Smith). Acta Protozool 32:123-125

Evdokimova EB (1977) Myxosporidians of teleost fishes from the Patagonian shelf (the Atlantic coast of Argentina). Parazitologiia 11:166-178

Fairbanks MB, Hoffert JR, Fromm PO (1969) The dependence of the oxygen-concentrating mechanism of the teleost eye (Salmo gairdneri) on the enzyme carbonic anhydrase. J Gen Physiol 54:203-211

Hoffman GL (1984) Two fish pathogens, Parvicapsula sp. and Mitraspora cyprini Myxosporea, new to North America. Symp Biol Hung 23:127-135

Johnstone AK (1984) Pathogenesis and life cycle of the myxosporean Parvicapsula sp. infecting marine cultured coho salmon. PhD thesis, University of Washington, Seattle

Kabata Z (1962) Five new species of Myxosporidia from marine fishes. Parasitology 52:177-186

Kent ML, Whitaker DJ, Dawe SC (1997) Parvicapsula minibicornis n. sp. (Myxozoa, Myxosporea) from the kidney of sockeye salmon (Oncorhynchus nerka) from British Columbia, Canada. J Parasitol 83:1153-1156

Kent ML, Andree KB, Bartholomew JL, El-Matbouli M and 12 others (2001) Recent advances in our knowledge of the Myxozoa. J Eukaryot Microbiol 48:395-413

Kovaljeva AA, Gayevskaya AV (1981) On the findings of myxosporidia of the genus Parvicapsula in the Atlantic fishes. Zool Zh 60:771-773

Landsberg JH (1993) Kidney myxosporean parasites in red drum Sciaenops ocellatus (Sciaenidae) from Florida, USA, with a description of Parvicapsula renalis n. sp. Dis Aquat Org 17:9-16

Lom J, Dykova I (1992) Protozoan parasites of fishes. Elsevier, Amsterdam

Raverty S, Kieser D, Bagshaw J, St-Hilaire S (2000) Renal infestation with Parvicapsula minibicornis in wild sockeye salmon from the Harrison and Adams rivers in British Columbia. Can Vet J 41:317-318

Shulman SS (1953) New and little known myxosporidia from the White Sea. Zool Zh 32:384-393

Shulman SS (1966) Miksosporidii Fauny SSSR. Nauka Publishers, Moscow-Leningrad (English translation, 1988. Myxosporidia of the USSR). Amerind Publishing, New Delhi

St-Hilaire S, Boichuk M, Barnes D, Higgins M and 5 others (2002) Epizootiology of Parvicapsula minibicornis in Fraser River sockeye salmon, Oncorhynchus nerka (Walbaum). J Fish Dis 25:107-120

Wittenberg JB, Wittenberg BA (1962) Active secretion of oxygen into the eye of fish. Nature 194:106-107

Zhao Y, Ma C, Song W (2000) Description of two new species of Parvicapsula Schulman, 1953 (Myxosporea: Parvicapsulidae) parasitic in the urinary bladder of marine fishes, Paralichthys olivaceus and Kareius bicoloratus, from the coast of Yellow Sea, China. Acta Protozool 39:157-162 